\title{
Determinants of Profitability: Evidence from Real Sector Firms Listed in Borsa Istanbul
}

\begin{abstract}
Özcan Işıı $\mathbf{k}^{\mathrm{a}}$
Abstract: The purpose of this study is to examine empirically the influence of firm-specific factors on the profitability for 153 listed real sector firms in Turkey for a period of eight years from 2005 to 2012. In our study, it is also analyzed if there are differences in firm profitability according to firm size and firm age. Estimation results obtained from the panel data models seem to imply that, on the whole, profitability measured by return on assets (ROA) of publicly traded real sector firms in Borsa Istanbul Stock Exchange is mostly driven by firm size, liquidity level, asset tangibility, debt structure measured by the ratio of total liabilities to total assets, stock return volatility, firm age, and financial crisis. On the other hand, the results of the conducted panel analysis reveal that growth opportunities measured by the ratio of capital expenditure to sales have no statistically significant impact on the profitability of real sector firms.
\end{abstract}

Keywords: Profitability, Real Sector Firms, Panel Data Analysis, Borsa Istanbul, Turkey

JEL Classification: D22, G32, L25

\section{Introduction}

As is well known, higher profitability not only allows firms to survive and succeed in a risky business environment, but is also important for sustainable economic growth (Lazăr, 2016). Besides, the analysis of the relationship between firm profitability and its determinants is critically crucial for both shareholders and uncountable stakeholders (Bhayani, 2010). Given that profitable firms make a great contribution to GDP and provide prosperity and employment opportunities, what determines the profitability of firms is of capital importance. In our study, we investigate the impact of firm specific factors on profitability of real sector firms listed in Borsa Istanbul Stock Exchange. In spite of the fact that there are a great number of researches done on the connection between firm profitability and its determinants in developed and emerging economies, detailed studies examining the factors which influence profitability of Turkish real sector firms are relatively few in number. Our study contributes to the existing literature in various ways. First, to better understand the influence of firm specific factors on profitability of real sector firms listed in Borsa Istanbul, we investigate both the full sample and firm size and age subsamples. Second, unlike the studies in Turkey, firm specific factors included in our regression equations are lagged one year except for industry and year dummies to control for endogeneity. Third, on account of the fact that the selected time span, from 2005 to 2012, contains the latest global financial crisis, the effect of this crisis on profitability of real sector firms in Turkey is also analyzed through a crisis dummy variable. Estimation results from the traditional panel data models i.e., the pooled-OLS seem to imply that, on the whole, profitability measured by return on assets (ROA) of

${ }^{a}$ Asst. Prof., PhD., Cumhuriyet University, Zara Veysel Dursun School of Applied Sciences, Department of Banking and Finance, Sivas, Turkiye, ozcan@live.com 
publicly traded real sector firms in Turkey is affected by all firm specific variables, namely firm size, liquidity level, asset tangibility, debt structure, stock return volatility, firm age, and crisis dummy variable except for sales growth.

The rest of our study is organized as follows. Section 2 overviews the literature review, the details of the dataset and methodology are described in Section 3. Section 4 presents the empirical results and finally, we summarize the main results of our analysis in section 5 .

\section{Literature Review}

On a sample of 782 firms in Slovenia in the years 2008 and 2009, Močnik and Širec (2015) try to identify the drivers of firm profitability by using a stepwise OLS. Their results indicate that the firm size and financial leverage are negatively correlated with ROA, whereas the labour cost is positively associated with firms' ROA.

Factors which influence profitability of 7158 firms listed in US stock exchanges during 1987-2006 are investigated by Lee (2009). The econometric results of fixed-effects dynamic panel data analysis provide evidence that past profitability, size, market share, market concentration, R\&D intensity, and inventory management are positively and significantly correlated with the ratio of net income plus advertising expenses to total assets (i.e. profit rate). However, the estimated relationship between size and profit rate is nonlinear.

What determines profitability of 20 cement firms quoted on Karachi Stock Exchange for the 20022012 period in Pakistan is empirically explored in a study by Hunjra et al. (2014). Results of panel data analysis imply that debt structure, growth, age, and size are the important determinants of profitability measured as ROA and ROE.

Lazăr (2016) empirically investigate the impacts of firm-specific variables on profitability of all firms quoted at Bucharest Stock Exchange during 2000-2011 employing OLS and fixed effects models. Estimation results for Romania indicate that greater debt structure, tangibles, size, and labour intensity lead to lower ROA, but greater sales growth and value added affect ROA positively.

Between the years 2011-2015, Mijić et al. (2016) study the profitability determinants of 12 firms operating meat industry in Serbia using random effect estimator. The results of the estimated models imply that higher liquidity level and growth rate of sales are positively correlated with profitability level. On the other hand, higher leverage level is negatively associated to profitability. However, the impact of firm size, asset tangibility, and investment ratio on profitability is not statistically significant.

Using a sample of 1020 non-financial Indian firms over the years 1988-1994, Majumdar (1997) reports that the ratio of imports to total operating expenses, the ratio of debt to equity, the ratio of inventory to total assets, firms' age are negatively and statistically significantly associated with profitability. On the other hand, firms' size, foreign ownership, firms' export orientation, the ratio of distribution to total operating expenses, and the ratio of marketing expenses to total operating expenses affect profitability positively and significantly.

In another study focusing on Indian firms for the years 2001-2008, Bhayani (2010) studies the factors that affect the profitability of 28 cement firms listed on the Bombay Stock Exchange. The results of backward regression analysis indicate that operating profit ratio, liquidity level, firm age, inflation rate, and interest rate are the most significant variables in the determination of the profitability of firms.

In a study on the food and beverage industry of Croatia, Pervan and Mlikota (2013) try to analysis what determines the profitability during the period from 1999 to 2009 by using dynamic panel analysis. Results of the analysis indicate that lagged profitability, size, and concentration ratio are found to be statistically significant variables which positively influence profitability. On the other hand, debt ratio is found to have a significant and negative correlation with profitability. 
What determines the profitability of 75 firms in the service sector in Portugal during the period from 1999 to 2003 is studied by Nunes et al. (2009). They try to estimate the association between profitability and its determinants with both dynamic and static panel models. According to their results, profitability measured by the ratio of operational results to total assets is lagged profitability, size, growth of sales, financial leverage, liquidity, and tangibility are the main determinants of profitability of firms operating in the service sector. More specifically, while greater lagged profitability, size, and growth of sales positively influence profitability; greater financial leverage, liquidity, and tangibility cause firms to have greater difficulties in profitability.

Nunes and Serrasqueiro (2015) explore the effects of micro-level variables on profitability of 187 knowledge-intensive business services firms in Portugal for the 2002-2009 period in the context of the dynamic panel data analysis. Their empirical results from system GMM and bias-corrected LSDV estimations show that size in terms of sales, liquidity, age, leverage measured by long-term debt, and R\&D expenditure have positive and significant effects on firm profitability, but there is a negative correlation between risk and profitability.

Using a sample of 119 firms listed on the Athens Exchange in Greece during 1995-2003 Asimakopoulo et al. (2009) explore the factors affecting the ratio of pre-tax profit to total assets. Results from panel regressions with fixed effects show that firm size in terms of sales, investment and growth in sales positively affect firm profitability, whereas current assets, leverage measured by the ratio of debt to total assets, the dummies represented by the participation in European Union and the adoption of the Euro negatively influence profitability of firms.

Pattitoni et al. (2014) study factors influencing profitability of 30.764 private firms in the EU-15 countries for the period from 2004 to 2011 using both static and dynamic panel data estimators. Estimation results suggest that leverage, working capital, sales growth, size in terms of total assets, opportunity cost of capital, ownership structure, GDP growth and inflation rate, and return of market indices are the main determinants of firms' ROA. In their non-linear models, they reveal the presence of nonlinear influences of size, growth and leverage (but not for working capital).

Using a large sample of 12.530 non-financial micro firms which operate in four different industry sectors (i.e. healthcare, transport, metal, and retail trade) over the 2006-2007 period, Yazdanfar (2013) investigates the determinants of Swedish firms' profitability levels. Based on results from the seemingly unrelated regression models, firm profitability, ROA, is positively influenced by firm size in terms of sales, growth and productivity. On the other hand, firm age has a significant and negative effect on firms' ROA. Besides, past ROA affects ROA positively and significantly for only firms operating in metal sector.

In Switzerland, Sweden and Italy, Hatem (2014) investigates the factors which explain the performance of 309 firms operating in professional activities, construction and other services and manufacturing sectors during the period 2003-2011. The author reports that firms' size, liquidity, firms' age, and growth opportunities are significant determinants of performance.

In Belgium, Spain, Italy, France and the UK, Goddard et al. (2005) investigate the determinants of 12.508 firms' profitability in manufacturing and service sector over the period 1993-2001 using dynamic panel data estimator. Their results reveal that size and gearing ratio have a negative influence on firms' ROA. In addition, firms holding a larger market share and higher liquidity tend to be more profitable.

For Turkey, Doğan and Topal (2016) try to explore the effects of firm specific factors on profitability of 136 firms traded on the Borsa Istanbul Stock Exchange for the time-period 2005-2012. The link between firm specific factors and profitability is examined through panel data analysis method. Estimation results show that while firm size is positively and significantly correlated to ROA and ROE, financial leverage level is negatively related to ROA and ROE in manufacturing industry. In addition, firm age and liquidity level are found to be statistically insignificant.

By using a sample of six listed firms which operate in paper and paper products industry in Borsa Istanbul Stock Exchange (BIST) for the period of 2011-2014, İslamoğlu and Çelik (2015) investigate the drivers 
of the profitability in terms of firm-specific, industry-specific and macroeconomic indicators in Turkey. Results of panel data fixed effects regressions implies that foreign trade deficit, the ratio of capital to asset, acid test ratio, market share, and net profit margin are positively and significantly related to profitability indicators measured by both ROA and ROE.

Korkmaz and Karaca (2014) use a sample of 78 Turkish listed firms and fixed and random effects estimations to analyze the influence of firm specific financial ratios on Turkish industrial firms' profitability for the period 2000-2011. Findings indicate that the ratio of debt to total asset, the ratio of fixed asset to total asset, the ratio of tangible asset to long-term liabilities, and the ratio of net sales to current asset are the important financial ratios explaining both ROA and ROE.

In another study focusing on an unbalanced panel of 408 Turkish firms traded on the Borsa Istanbul Stock Exchange covering the years 2005-2014, Akben-Selcuk (2016) examines whether the firm specific factors explain firm performance. Panel data estimation results reveal that debt and R\&D expenditures are negatively and significantly related to ROA, whereas the impact of past ROA, liquidity level, size, growth in net sales, and dummy variable for exports on ROA is found to be positive and significant.

\section{Methodology and Data}

\subsection{Empirical Methodology}

The following regression equation which is similar to that of Majumdar (1997), Asimakopoulo et al. (2009), Nunes et al. (2009), and Yazdanfar (2013) is developed with the aim of examining the association between selected financial variables and firm profitability:

$$
\text { Profitability }_{\text {it }}=\alpha_{0}+\alpha_{1} \mathrm{FSV}_{\mathrm{it}-1}+\text { Year }_{\mathrm{t}}+\operatorname{Ind}_{\mathrm{i}}+\epsilon_{\mathrm{it}}
$$

In this model Profitability $y_{i t}$ is the return on assets of firm i in period $t ; \alpha_{0}$ is an intercept; the vector FSV $_{\text {it-1 }}$ denotes a set of firm specific variables. While Year $r_{t}$ is a vector of year dummies, $\operatorname{Ind}_{\mathrm{i}}$ is a vector of industry dummies; $\alpha_{0}$ and $\alpha_{1}$ are coefficients, and finally $\epsilon_{i t}$ is the random disturbance.

It is also analyzed if there are differences in firm profitability according to firm size and firm age i.e., we divide the firms into small and big firms by using the median value of firm size variable (we classify listed firms as "small firm" if total assets value of firms in the sample is smaller than the median value, and "big firm" otherwise). Besides, our sample is also divided into two subsamples of young and old firms, taking into account the median age of firms (we classify listed firms as "young firm" when firm age variable is less than the sample median value, and "old firm" otherwise). A detailed summary of firm specific variables employed in our study and their predicted coefficient signs are provided in Table 1. We expect the coefficients of these variables to take the following signs:

Firm size: There appears to be a consensus that firm profitability is directly associated with firm size defined as the natural logarithm of total assets. According to the economies of scale hypothesis, large firms are more likely to lessen their costs, have competitive power and heighten profitability of their assets (Bhayani, 2010; Yazdanfar, 2013; Hatem, 2014). In this situation the coefficient estimate for firm size is anticipated to be positive. Alternatively, a negative association between size and profitability may suggest that assets are not employed efficiently (Goddard et al. 2005; Pervan and Mlikota, 2013; Pattitoni et al. 2014).

Growth opportunities: According to previous studies such as Greiner (1972), Nunes et al. (2009), and Pattitoni et al. (2014), impact of growth opportunities on profitability could be ambiguous. In other words, growth opportunities may help heighten the motivation of employees and, therefore, profitability of firm. However, growth opportunities may lead to a deep concern between employees because of decreasing informal relationships, which results in lower profitability.

Liquidity: This variable, represented by the ratio of current assets to short-term liabilities, is a crucial firm-specific determinant of profitability. Liquidity may be expected to have a negative coefficient in Eq. (1) given that a higher level of liquidity is likely to create a problem regarding over-investment (Bhayani, 2010; 
Hatem, 2014). However, according to Goddard et al. (2005), the sign of the liquidity variable could be positive because of utilizing lucrative long term investment opportunities. Besides, Firms with high liquidity levels is less likely to be affected by sudden changes in the market in which they operate (Petracci and Spisni, 2014).

Asset tangibility: this indicator, which is represented by the ratio of fixed assets to total assets, is an important determinant affecting firm profitability in the empirical researches. According to Nunes et al. (2009), Bhutta and Hasan (2013), Korkmaz and Karaca (2014), and Lazăr (2016), asset tangibility and profitability are negatively related since firms having more tangible assets are anticipated to hold less liquid assets, and therefore, firms with more liquid assets are more likely to benefit from lucrative long term investment opportunities.

Debt structure: As stated by Asimakopoulos et al. (2009) and Pervan and Mlikota (2013) a rise in debt ratio causes firms to pay high interest periodically, which results in poorer performance and lower profitability. Consequently, we expect to find a negative linkage between debt structure and profitability. On the other hand, Majumdar (1997) asserts that a high degree of financial leverage causes managers to employ firm resources more efficiently and, therefore, profitability may increases.

Return volatility: This variable, defined as the standard deviation of monthly stock returns for the prior 12 months, may be anticipated to have a positive influence on profitability taking the utilization of inside information into account (Demsetz and Villalonga, 2001; Pervan and Mlikota, 2013). On the other hand, earlier empirical studies by Marcelo et al. (2014) and Poutziouris et al. (2015) report a negative linkage between firm specific risk and profitability of firm.

Age: As pointed out by Majumdar (1997), this variable is likely to be expected to take a positive or negative sign. On the one hand, older firms may have better experience, reputation, and access to financial resources due to longer relationships with financial institutions than younger firms, which results in higher profitability (Yazdanfar, 2013; Hatem, 2014). On the other hand, the influence of aging on profitability of firms could be negative by virtue of the inertia and the bureaucratic ossification and these conditions may cause firms to have problems with keeping pace with changes in market conditions (Barron et al. 1994; Majumdar, 1997).

Financial crisis: This indicator, which takes a value of one when the years are 2008 and 2009 and zero otherwise, is included in the analysis to control for the influence of the latest financial crisis. We would expect financial crisis dummy variable to be linked with lower profitability.

Table 1. Definition of Variables Used in This Study

\begin{tabular}{|c|c|c|c|}
\hline Variables & Notation & Definition & $\begin{array}{l}\text { Predicted } \\
\text { sign }\end{array}$ \\
\hline \multicolumn{4}{|c|}{ Panel A: Profitability variable } \\
\hline Return on assets & ROA & Return over total assets & \\
\hline \multicolumn{4}{|c|}{ Panel B: Firm-specific variables } \\
\hline Size & SIZE & The natural logarithm of the firm's total assets & $+/-$ \\
\hline $\begin{array}{l}\text { Growth } \\
\text { opportunities }\end{array}$ & GROWTH & Capital expenditure over sales & $+/-$ \\
\hline Liquidity & LIQ & Current assets over short term liabilities & $+/-$ \\
\hline Tangibility & TAN & Fixed assets over total assets & - \\
\hline Debt structure & LEV & Total liabilities over total assets & $+/-$ \\
\hline Return volatility & VOL & $\begin{array}{l}\text { The standard deviation of monthly stock returns for the } \\
\text { prior } 12 \text { months }\end{array}$ & + \\
\hline Age & AGE & $\begin{array}{l}\text { The natural log of the number of years since the firm's } \\
\text { incorporation }\end{array}$ & $+/-$ \\
\hline \multicolumn{4}{|c|}{ Panel C: Control variable } \\
\hline Financial Crisis & FC & $\begin{array}{l}\text { 1: if the years equal to } 2008 \text { and } 2009 \\
\text { 0: the other years }\end{array}$ & - \\
\hline
\end{tabular}




\subsection{Data Analysis}

To explore the associations between firm characteristics and profitability, we focus our analysis on Turkish listed firms i.e. we use a sample of all firms traded in Borsa Istanbul Stock Exchange between 2005 and 2012. Financial firms and firms with negative equity capital are eliminated from sample. Overall, the final sample of our study is composed of 153 publicly traded firms from 8 sectors based on BIST classification and the sample period covers the years of 2005-2012.

Summary statistics on dataset used in our study over the period of 2005-2012 are presented in Table 2. The mean (median) values for ROA of sample firms is $4.37 \%$ (3.83\%). The highest value of ROA is $79.36 \%$, while the lowest value for ROA is $-33.4 \%$. Standard deviation of this ratio has value $9.85 \%$. In comparison with other countries, the mean value of ROA of real sector firms in Turkey is far smaller than that of firms located in five large European countries, such as Belgium (6.26\%), France (8.35\%), Italy (7.74\%), Spain (8.53\%), and the UK (8.72\%) (Goddard et al. 2005). Besides, we can say that, except for tangibility of assets, debt structure, and firm age, there is a wide variation in firm characteristics as well as in firm profitability measure. In other words, we find volatility is not very high for asset tangibility, debt ratio, and age variable owing to the fact that their standard deviations are under the respective averages. Table 3 reports the sectors in which listed real sector firms operate. As can be seen from Table 3, approximately $79 \%$ of listed firms operate in manufacturing sector.

Table 2. Descriptive Statistics

\begin{tabular}{lccccc}
\hline Variable & Mean & Median & SD & Min. & Max. \\
\hline ROA & .0437 & .0383 & .0985 & -.3340 & .7936 \\
SIZE & 907.1107 & 218.36 & 2172.14 & 7.7520 & 18780.90 \\
GROWTH & .1673 & .1055 & .6571 & -1 & 11.7582 \\
LIQ & 2.7328 & 1.6439 & 4.6628 & .0022 & 79.2500 \\
TAN & .5002 & .5004 & .2143 & .0004 & .9990 \\
LEV & .4336 & .4120 & .2563 & .0064 & 4.2296 \\
VOL & .0216 & .0008 & .1935 & .0002 & 5.8864 \\
AGE & 34.7157 & 36 & 14.1667 & 2 & 101 \\
FC & .25 & 0 & .4332 & 0 & 1 \\
\hline
\end{tabular}

Note: Figures on size variable are in Million Turkish Lira. Variable definitions are given in Table 1.

Table 3. Breakdown of Sample Firms by Sector

\begin{tabular}{lc}
\hline Sector & Number of firms \\
\hline Mining & 2 \\
Manufacturing & 121 \\
Electricity, Gas and Water & 3 \\
Construction & 1 \\
Wholesale and Retail Trade, Hotels and Restaurants & 12 \\
Transportation and Telecommunication & 4 \\
Education, Health and Sports & 1 \\
Technology & 9 \\
Total & $\mathbf{1 5 3}$ \\
\hline
\end{tabular}

Table 4 presents the pairwise correlation matrix for profitability and firm characteristics that we use in Eq. (1).There are significant correlations between firm-specific indicators and firm profitability measure. As can be seen from Table 4, the maximum correlation coefficient of -.37 is found between leverage level and liquidity level. In an additional variance inflation factors (VIFs) analysis, the highest VIF value is found to be 3.05. These results show that there is no severe multicollinearity problem in our regression models. 
O. Isik

Table 4. Pairwise Correlation Matrix

\begin{tabular}{|c|c|c|c|c|c|c|c|c|c|c|}
\hline & ROA & SIZE & GROWTH & LIQ & TAN & LEV & VOL & AGE & FC & VIF \\
\hline ROA & 1 & & & & & & & & & \\
\hline SIZE & $.34 *$ & 1 & & & & & & & & 1.28 \\
\hline GROWTH & $.13^{*}$ & .04 & 1 & & & & & & & 1.05 \\
\hline LIQ & $.10^{*}$ & $-.15^{*}$ & -.04 & 1 & & & & & & 1.32 \\
\hline TAN & $-.12 *$ & $.09 *$ & -.003 & -.001 & 1 & & & & & 1.34 \\
\hline LEV & $-.24 *$ & $.10 *$ & .02 & $-.37 *$ & $-.19 *$ & 1 & & & & 1.35 \\
\hline VOL & .005 & -.06 & .03 & $.13^{*}$ & -.06 & -.05 & 1 & & & 1.14 \\
\hline AGE & $.16^{*}$ & $.30 *$ & -.05 & -.03 & $.11 *$ & $-.12 *$ & $-.14^{*}$ & 1 & & 1.44 \\
\hline FC & $-.08 *$ & -.001 & $-.12 *$ & -.001 & .02 & .03 & -0.06 & .006 & 1 & 3.05 \\
\hline
\end{tabular}

\section{Empirical Results}

Based on the regression results from Table 4, we find a positive and statistically significant correlation between firm size measured by the natural logarithm of the firms' total assets and firm profitability in both total sample and subsamples. These results regarding size variable mean that the firms having more assets can diminish their costs and increase their profitability level owing to the scale economies idea. Generally, our results in terms of size are similar to those of Majumdar (1997) for India; Pervan and Mlikota (2013) for Croatia; Nunes and Serrasqueiro (2015) and Nunes et al. (2009) for Portugal, Yazdanfar (2013) for Sweden, Andres (2008) for Germany, and Asimakopoulo et al. (2009) for Greece. However, these results contradict those of Goddard et al. (2005) for Belgium, Spain, Italy, France, and the UK, Močnik and Širec (2015) for Slovenia, Hunjra et al. (2014) for Pakistan, and Saito (2008) for Japan.

Growth variable, which is calculated as the ratio of capital expenditures to sales, is positively associated with profitability except for big firms' sample. The link between growth opportunities and profitability is, however, statistically insignificant in each regressions. The influence of growth on profitability is found to be significant and positive in previous studies such as Mijić et al. (2016), Poutziouris et al. (2015) and Miralles-Marcelo et al. (2014).

The result for big firms (regression 4) indicates that the influence of liquidity on profitability is positive and statistically significant. This result shows that liquidity is a significant determinant of profitability for big quoted firms. This means that bigger quoted firms having a higher liquidity ratio perform better. This finding for big firms is in line with the findings of Nunes and Serrasqueiro (2015) for Portugal, Mijić et al. (2016) for Serbia, Bhayani (2010) for India, and Goddard et al. (2005) for Belgium, Spain, Italy, France.

The estimated coefficient of the tangible assets, as shown in Table 4, turns out to be negative for total sample and subsamples, but insignificant only in young firms' sample. This implies that, for Turkish listed firms, the level of tangible assets is a significant driver of profitability. Consequently firms with higher tangible assets perform worse due to increased risk. This finding contradicts that of Majumdar (1997), however is in line with that of Lazăr (2016).

As expected, the estimated coefficient on debt structure, LEV, is significant for full sample and subsamples except for young firms, suggesting that higher debt ratio leads to lower profitability. In other words, firms having higher level of leverage in both full sample and sub-samples perform worse in terms of profitability. This finding that the leverage is negatively and significantly associated with profitability parallels the findings of Majumdar (1997) for India; Andres (2008) for Germany; Asimakopoulos et al. (2009) for Greece; Nunes et al. (2009) for Portugal; Pattitoni et al. (2014) for the EU-15 countries, Pervan and Mlikota (2013) for Croatia; Miralles-Marcelo et al. (2014) for Portugal and Spain; Poutziouris et al. (2015) for UK; and Mijić et al. (2016) for Serbia; among others.

The impact of stock return volatility, as measured by the standard deviation of monthly stock returns, on profitability is significant for small, young and old firms' samples. While higher volatility leads to lower 
profitability of small and young firms in our sample, it causes old firms to have higher ROA. For Spain and Portugal Miralles-Marcelo et al. (2014) report that firm risk for small, big, young and old firms' samples is negatively and significantly associated with ROA. Likewise, the negative association for firm risk is found by Poutziouris et al. (2015) for the UK. However, Pervan and Mlikota (2013) conclude that firm risk is positively and insignificantly correlated with the profitability of firms in Croatia.

The relationship between AGE and profitability is not significant except for small firms' sample. This indicates that as small firms get older, their profitability increases as well. This result is consistent with result of Miralles-Marcelo et al. (2014) exploring a sample of publicly trading small firms in Portugal. However, Yazdanfar (2013) reports that firms' age is negatively and significantly linked to profitability of Swedish micro firms. Similarly, the negative link is also supported by Poutziouris et al. (2015) for UK listed firms, Andres (2008) for listed German firms, Liu et al. (2015) for Chinese listed firms, and Saito (2008) for publicly traded firms in Japan.

The influence of financial crisis on listed real sector firms' profitability is negative in total sample and all subsamples, but this influence is only significant for total sample and big firms' sample. A negative relationship between financial crisis and profitability implies that financial crisis leads to lower ROA.

Table 5. The Association Between Firm Characteristics and Profitability

\begin{tabular}{|c|c|c|c|c|c|}
\hline \multirow[b]{2}{*}{ Independent variable } & \multicolumn{5}{|c|}{ Dependent variable: ROA } \\
\hline & $\begin{array}{c}\text { Full firms } \\
\text { sample (1) }\end{array}$ & $\begin{array}{l}\text { Small firms } \\
\text { sample (2) }\end{array}$ & $\begin{array}{c}\text { Big firms } \\
\text { sample (3) }\end{array}$ & $\begin{array}{c}\text { Young firms } \\
\text { sample (4) }\end{array}$ & $\begin{array}{c}\text { Old firms } \\
\text { sample (5) }\end{array}$ \\
\hline Constant & $\begin{array}{l}-.0135 \\
(.0476)\end{array}$ & $\begin{array}{c}.0397 \\
(.0711)\end{array}$ & $\begin{array}{c}.0654 \\
(.0639)\end{array}$ & $\begin{array}{c}-.1377^{* *} \\
(.0608)\end{array}$ & $\begin{array}{l}.1862^{*} \\
(.1017)\end{array}$ \\
\hline SIZE & $\begin{array}{l}.0238 * * * \\
(.0050)\end{array}$ & $\begin{array}{l}.0165^{*} \\
(.0091)\end{array}$ & $\begin{array}{l}.0232 * * \\
(.0099)\end{array}$ & $\begin{array}{c}.03154 * * * \\
(.0078)\end{array}$ & $\begin{array}{l}.0203 * * * \\
(.0047)\end{array}$ \\
\hline GROWTH & $\begin{array}{c}.0066 \\
(.0045)\end{array}$ & $\begin{array}{l}.01021 \\
(.0070)\end{array}$ & $\begin{array}{l}-.0073 \\
(.0080)\end{array}$ & $\begin{array}{c}.0081 \\
(.0058)\end{array}$ & $\begin{array}{c}.0019 \\
(.0089)\end{array}$ \\
\hline LIQ & $\begin{array}{c}.0010 \\
(.0011)\end{array}$ & $\begin{array}{c}.0006 \\
(.0009)\end{array}$ & $\begin{array}{l}.0078 * * \\
(.0035)\end{array}$ & $\begin{array}{c}.0011 \\
(.0008)\end{array}$ & $\begin{array}{l}-.0006 \\
(.0011)\end{array}$ \\
\hline TAN & $\begin{array}{c}-.0842 * * * \\
(.0255)\end{array}$ & $\begin{array}{c}-.0950 * * * \\
(.0319)\end{array}$ & $\begin{array}{l}-.0559 * \\
(.0316)\end{array}$ & $\begin{array}{l}-.0143 \\
(.0264)\end{array}$ & $\begin{array}{c}-.1614^{* * *} \\
(.0294)\end{array}$ \\
\hline LEV & $\begin{array}{c}-.0992 * * * \\
(.0366)\end{array}$ & $\begin{array}{l}-.0692 * \\
(.0365)\end{array}$ & $\begin{array}{c}-.1220 * * \\
(.0441)\end{array}$ & $\begin{array}{l}-.0465 \\
(.0281)\end{array}$ & $\begin{array}{c}-.2059 * * * \\
(.0403)\end{array}$ \\
\hline VOL & $\begin{array}{l}-.0113 \\
(.0128)\end{array}$ & $\begin{array}{c}-.0165 * * * \\
(.0054)\end{array}$ & $\begin{array}{c}.0398 \\
(.0453)\end{array}$ & $\begin{array}{c}-.0154 * * * \\
(.0045)\end{array}$ & $\begin{array}{c}.1328 * * * \\
(.0312)\end{array}$ \\
\hline AGE & $\begin{array}{c}.0143 \\
(.0108)\end{array}$ & $\begin{array}{l}.0360 * * \\
(.0154)\end{array}$ & $\begin{array}{l}-.0112 \\
(.0152)\end{array}$ & $\begin{array}{c}.0119 \\
(.0096)\end{array}$ & $\begin{array}{l}-.0296 \\
(.0263)\end{array}$ \\
\hline FC & $\begin{array}{c}-.0286 * * \\
(.0104)\end{array}$ & $\begin{array}{l}-.0026 \\
(.0136)\end{array}$ & $\begin{array}{c}-.0397^{* * *} \\
(.0135)\end{array}$ & $\begin{array}{l}-.0042 \\
(.0157)\end{array}$ & $\begin{array}{l}-.0168 \\
(.0105)\end{array}$ \\
\hline Year dummies & Yes & Yes & Yes & Yes & Yes \\
\hline Industry dummies & Yes & Yes & Yes & Yes & Yes \\
\hline Autocorrelation test & 1.651 & $14.150 * * *$ & 0.272 & 0.002 & 2.206 \\
\hline Heteroskedasticity test & $16.39 * * *$ & $25.87 * * *$ & $50.56 * * *$ & 0.15 & $21.96 * * *$ \\
\hline Sample size & 1044 & 493 & 551 & 487 & 557 \\
\hline Root MSE & .08948 & .08475 & .09068 & .09181 & .07989 \\
\hline Adj.R-squared & 0.2391 & 0.2065 & 0.2126 & 0.3024 & 0.2906 \\
\hline
\end{tabular}

Note: Robust standard errors are shown in parentheses. Variable definitions are given in Table 1. All independent variables except for year and industry dummies are lagged by one year to diminish endogeneity problems.* suggests that the statistic is significant at 0.10 level. ${ }^{* *}$ suggests that the statistic is significant at 0.05 level. ${ }^{* * *}$ suggests that the statistic is significant at 0.01 level. 


\section{Conclusion}

This study explores the determinants of profitability of 153 real sector firms listed in Borsa Istanbul Stock Exchange for a period of 8 years from 2005 to 2012 by employing the panel regression analysis technique. Firm profitability are mostly determined by firm-specific factors such as firm size, liquidity level, asset tangibility, debt ratio, stock return volatility, firm age, and financial crisis during the period under consideration. In other words, main findings in our study show that: (i) firm size is extremely influential on profitability of firms as it is positive and significant in both full sample and subsamples, suggesting that larger firm size leads to higher ROA; (ii) liquidity level is found to be positive and significant only in big firms' sample, which implies that a higher level of liquidity leads to higher ROA; (iii) larger tangibility ratio causes profitability to decrease significantly, while it is insignificant in young firms sample; (iv) higher leverage ratio significantly lower the ROA ratio. This relationship is, however, insignificant for young firms' sample; ( $v$ ) the impact of stock return volatility on profitability is negative and significant for small and young firms' sample. This implies that increased risk for smaller and younger firms leads to lower ROA. On the other hand, there is a positive association between firm risk and firm profitability in old firms' sample. This means that increased risk significantly increases profitability of older firms; (vi) the variable firm age is only significant for small firms' sample. According to this finding, increasing firm age enhances the ROA; (vii) the impact of financial crisis on firm profitability is negative in the full sample and also in subsamples, whereas it is only significant for full firms and big firms samples, implying that financial crisis leads to lower profitability.

In our analysis, we use only firm characteristics as independent variables. For further studies, macroeconomic-related variables (i.e. economic growth and inflation rate) could be incorporated into profitability model. Since the majority of firms traded on Borsa Istanbul Stock Exchange have operated in the manufacturing sector, it may be more meaningful to investigate the factors that affect the profitability of this sector together with other sectors. Also, dynamic panel data estimators as well as the traditional panel data estimators could be used for further analysis.

\section{References}

Akben-Selcuk, E. (2016). Factors affecting firm competitiveness: evidence from an emerging market. International Journal of Financial Studies, 4(9), 1-10.

Andres, C. (2008). Large shareholders and firm performance-An empirical examination of founding-family ownership. Journal of Corporate Finance, 14(4), 431-445.

Asimakopoulos, I., Samitas, A., \& Papadogonas, T. (2009). Firm-specific and economy wide determinants of firm profitability: Greek evidence using panel data. Managerial Finance, 35(11), 930-939.

Barron, D. N., West, E., \& Hannan, M. T. (1994). A time to grow and a time to die: Growth and

mortality of credit unions in New York City, 1914-1990. American Journal of Sociology, 100(2), 381-421.

Bhayani, S. J. (2010). Determinant of profitability in Indian cement industry: An economic analysis. South Asian Journal of Management, 17(4), 6-20.

Bhutta, N.T., \& Hasan, A. (2013). Impact of firm specific factors on profitability of firms in food sector. Open Journal of Accounting, 2, 19-25.

Demsetz, H., \& Villalonga, B. (2001). Ownership structure and corporate performance. Journal of Corporate Finance, 7(3), 209-233.

Doğan, M., \& Topal, Y. (2016). Karlılığı belirleyen finansal faktörler: BIST'te işlem gören imalat sanayi firmaları üzerine bir araştirma. Optimum Ekonomi ve Yönetim Bilimleri Dergisi, 3(1), 55-66.

Goddard, J., Tavakoli, M., \& Wilson, J. O. S. (2005). Determinants of profitability in European manufacturing and services: Evidence from dynamic panel model. Applied Financial Economics, 15(18), 1269-1282.

Greiner, L. (1972). Evolutions and revolutions as organizations grow. Harvard Business Review, 50(4), 37-46.

Hatem, B. S. (2014). Determinants of firm performance: a comparison of European countries. International Journal of Economics and Finance, 6(10), 243-249. 
Hunjra, A. I, Chani, M. I., Javed, S., Naeem, S., \& ljaz, M.S. (2014). Impact of micro economic variables on firms performance. International Journal of Economics and Empirical Research, 2(2), 65-73.

Islamoglu, M., \& Celik, N. (2015). Financial performance determinants of paper and paper products firms listed in Borsa Istanbul. International Journal of Economics and Finance, 7(4), 233-243.

Korkmaz, Ö., \& Karaca, S. S. (2014). Üretim Isletmelerinde firma karliliginin finansal belirleyicileri ve BIST imalat sanayi uygulamasi. Ege Akademik Bakis, 14(1), 21-29.

Lazăr, S. (2016). Determinants of firm performance: Evidence from Romanian listed companies. Review of Economic and Business Studies, 9(1), 53-69.

Liu, Y., Miletkov, M. K., Wei, Z., \& Yang, T. (2015). Board independence and firm performance in China. Journal of Corporate Finance, 30, 223-244.

Lee, J. (2009). Does size matter in firm performance? Evidence from US public firms. International Journal of the Economics of Business, 16(2), 189-203.

Majumdar, S. K. (1997). The impact of size and age on firm-level performance: Some evidence from India. Review of Industrial Organization, 12(2), 231-241.

Mijić, K., Zekić, S., \& Jakšić, D. (2016). Profitability analysis of meat industry in Serbia. FACTA UNIVERSITATISEconomics and Organization, 13(4), 379-386.

Miralles-Marcelo, J. L., del Mar Miralles-Quirós, M., \& Lisboa, I. (2014). The impact of family control on firm performance: Evidence from Portugal and Spain. Journal of Family Business Strategy, 5(2), 156-168.

Močnik, D., \& Širec, K. (2015). Determinants of a fast-growing firm's profits: Empirical evidence for Slovenia. Annals of the Alexandru loan Cuza University-Economics, 62(1), 37-54.

Nunes, P. M., \& Serrasqueiro, Z. (2015). Profitability determinants of Portuguese knowledge-intensive business services: Empirical evidence using panel data models. Applied Economics Letters, 22(1), 51-56.

Nunes, P. M., Serrasqueiro, Z. M., \& Sequeira, T. N. (2009). Profitability in Portuguese service industries: A panel data approach. The Service Industries Journal, 29(5), 693-707.

Pattitoni, P., Petracci, B., \& Spisni, M. (2014). Determinants of profitability in the EU-15 area. Applied Financial Economics, 24(11), 763-775.

Pervan, M., \& Mlikota M. (2013). What determines the profitability of companies: Case of croatian food and beverage industry. Economic Research-Ekonomska Istraživanja, 26(1), 277-286.

Poutziouris, P., Savva, C. S., \& Hadjielias, E. (2015). Family involvement and firm performance: Evidence from UK listed firms. Journal of Family Business Strategy, 6(1), 14-32.

Saito, T. (2008). Family firms and firm performance: Evidence from Japan. Journal of the Japanese and International Economies, 22(4), 620-646.

Yazdanfar, D. (2013). Profitability determinants among micro firms: evidence from Swedish data. International Journal of Managerial Finance, 9(2), 151-160. 